\title{
Non-human Clinical Subject Data Section
}

National Cancer Institute

\section{Source}

National Cancer Institute. Non-human Clinical Subject Data Section. NCI Thesaurus. Code C105755.

A section within the study document pertaining to data collected from non-human clinical study subjects. 